\title{
Evaluation of micronutrients among pediatric liver cirrhosis in Shiraz, Iran
}

\author{
Seyed Mohsen Dehghani ${ }^{1}$, Anis Amirhakimi ${ }^{2}$, Parisa Baligh ${ }^{3}$ and Hazhir Javaherizadeh ${ }^{4 *}$ (D)
}

\begin{abstract}
Background: Cirrhosis is the final result of most types of liver disease. Zinc, magnesium, and vitamin D have a significantly vital role in the immunologic and physiologic mechanisms in the body. The current study aimed to measure magnesium, zinc, and vitamin D level among children with liver cirrhosis.

Results: One hundred cases were included in the current study. Vitamin D deficiency was found in 53\% of the cases. Zinc deficiency was present in $23 \%$ of the cases. The magnesium level was more than the normal level among $99 \%$ of the cases. There is a significant inverse correlation between zinc level and PELD score (Pearson correlation $=-0.314$, $P=0.007)$.

Conclusion: Zinc deficiency and vitamin D deficiency were seen in children with liver cirrhosis. Serum magnesium level in children with liver cirrhosis was higher than standard. A significant correlation was seen between zinc level and PELD score.
\end{abstract}

Keywords: Cirrhosis, Liver, Magnesium, Zinc

\section{Backgrounds}

The liver is the primary organ for metabolism. Liver disease has a profound effect on protein and energy metabolism [1, 2]. Cirrhosis of the liver has several etiology including biliary atresia, Wilson's disease, and autoimmune hepatitis [3]. Zinc is an essential trace element with various biological actions [4]. In patients with hepatic encephalopathy, zinc deficiency may have a role. Zinc supplementation for the treatment of hepatic encephalopathy was proposed in the literature [5-7]. Magnesium deficiency was reported among $30 \%$ of children with liver disease [8]. Vitamin D deficiency is an independent risk factor for infection among children with cirrhosis [9]. There are limited studies about zinc, magnesium, and vitamin $\mathrm{D}$ deficiencies among children with liver cirrhosis. This study aimed to evaluate the level of zinc, magnesium, and vitamin D among children with liver cirrhosis.

\footnotetext{
*Correspondence: Hazhirja@yahoo.com

${ }^{4}$ Alimentary Tract Research Center, Ahvaz Jundishapur University of Medical Sciences, Clinical Sciences Research Institute, Ahvaz, Iran Full list of author information is available at the end of the article
}

\section{Methods}

In this cross-sectional study, all children aged less than 18 years with liver cirrhosis who visited at Pediatric Gastroenterology and Hepatology Clinic of Shiraz University of Medical Sciences were included. The duration of the study was 2 years starting from February 2017. Children with a history of zinc, magnesium, and vitamin D supplementation before the diagnosis of cirrhosis were excluded from the study. Cirrhosis was confirmed after liver biopsy in children using the clinical and radiologic criteria for liver biopsy. For zinc, magnesium, and vitamin D measurement; $5 \mathrm{ml}$ of blood sample was obtained. Zinc and magnesium level measurement was done using atomic absorption spectrometry. Normal zinc level was considered to be $50-150 \mathrm{mcg} / \mathrm{dl}$. The normal level of magnesium was considered to be $0.8-1 \mathrm{mmol} / \mathrm{dl}$. The normal level of vitamin D was considered to be $20-100 \mathrm{ng} / \mathrm{dl}$. In the current study, standard levels of zinc, magnesium, and vitamin D were used for comparison as control.

This study was approved by the ethical committee of the Shiraz University of Medical Sciences. An informed consent form was signed by parents. SPSS ver 25.0 was 
Table 1 Etiology of liver cirrhosis

\begin{tabular}{ll}
\hline Etiology & Frequency (\%) \\
\hline Cryptogenic cirrhosis & 15 \\
Progressive familial intrahepatic cholestasis & 26 \\
Biliary atresia & 27 \\
Autoimmune hepatitis & 6 \\
Neonatal hepatitis & 6 \\
Wilson's disease & 5 \\
Tyrosinemia & 6 \\
Idiopathic neonatal hepatitis & 3 \\
Primary sclerosing cholangitis & 2 \\
Congenital heart failure & 1 \\
Intrahepatic bile duct paucity (non-syndromatic) & 2 \\
Allagile syndrome & 1 \\
\hline
\end{tabular}

normal range. Among 31\% of the cases, the albumin level was lower than the normal range.

INR was normal among 59\% of children with liver cirrhosis. The mean of INR was 1.334 , and the median was $1.1(\min =0.94, \max =4.7)($ Table 2$)$.

The minimum and maximum of serum $\mathrm{Na}$ were 128 and 158, respectively. The mean of serum Na was 137.9 $\mathrm{meq} / \mathrm{dl}$.

PELD score was used for $89 \%$ of the children. Among $31 \%$ of children, the PELD score was 1 . The MELD score was used for $11 \%$ of children. The minimum and maximum MELD scores were 6 and 17, respectively.

Zinc level distribution was normal using the Kolmogorov-Smirnov test. The mean of zinc level (71.32 $\pm 25.01)$ was significantly lower than normal population $(P$ value $=0.0001$, CI95\% $=65.5-76.5)$ (Fig. 1$)$ (Table 3).

Table 2 Liver function test among children with liver disease

\begin{tabular}{|c|c|c|c|c|c|c|c|c|}
\hline \multicolumn{9}{|c|}{ Descriptive statistics } \\
\hline & \multirow{2}{*}{$\begin{array}{l}N \\
\text { Statistic }\end{array}$} & \multirow{2}{*}{$\begin{array}{l}\text { Range } \\
\text { Statistic }\end{array}$} & \multirow{2}{*}{$\begin{array}{l}\text { Minimum } \\
\text { Statistic }\end{array}$} & \multirow{2}{*}{$\begin{array}{l}\text { Maximum } \\
\text { Statistic }\end{array}$} & \multicolumn{2}{|l|}{ Mean } & \multirow{2}{*}{$\begin{array}{l}\text { Std. deviation } \\
\text { Statistic }\end{array}$} & \multirow{2}{*}{$\begin{array}{l}\text { Variance } \\
\text { Statistic }\end{array}$} \\
\hline & & & & & Statistic & Std. Error & & \\
\hline Albumin & 100 & 3.30 & 1.20 & 4.50 & 3.6810 & .05479 & .54785 & .300 \\
\hline INR & 99 & 3.76 & .94 & 4.70 & 1.3343 & .05583 & .55552 & .309 \\
\hline Total bilirubin & 100 & 32.00 & .50 & 32.50 & 5.2163 & .64702 & 6.47024 & 41.864 \\
\hline AST & 100 & 1444.00 & 11.00 & 1455.00 & 195.7800 & 23.25283 & 232.52829 & $54,069.406$ \\
\hline ALT & 100 & 1588.20 & 1.80 & 1590.00 & 138.6380 & 20.37269 & 203.72693 & $41,504.664$ \\
\hline
\end{tabular}

used for data analysis. The chi-square test was used for comparison.

\section{Results}

In the current study, 100 children $(m=52, f=48)$ aged less than 18 years were finally included. The mean age of the cases was $7.17 \pm 4.84$ ( $\min =5$ months, $\max =$ 18 years) years with a median age was 6.0 years. Biliary atresia and progressive familial intrahepatic cholestasis were the most frequent etiology of liver cirrhosis among our cases (Table 1).

Hepatic encephalopathy was seen in $2 \%(n=2)$ of the cases. Among 2 children with hepatic encephalopathy, one child had zinc deficiency.

Ascites were the most common finding among children with liver cirrhosis and were seen in $21 \%$ of children. Among the children, $10 \%$ had a history of gastrointestinal bleeding.

The mean of albumin was 3.681 with minimum and maximum levels of $1.2 \mathrm{~g} / \mathrm{dl}$ and $4.5 \mathrm{~g} / \mathrm{dl}$, respectively. Among $69 \%$ of cases, the albumin level was in the
The minimum and maximum levels of zinc were 25.2 $\mathrm{mcg} / \mathrm{dl}$ and $147.1 \mathrm{mcg} / \mathrm{dl}$, respectively. Zinc level was lower than the normal range among $23 \%$ of children with liver cirrhosis. The mean level of zinc was $71.32 \pm$ $25.01 \mathrm{mcg} / \mathrm{dl}$. The median level of zinc was $69.7 \mathrm{mcg} / \mathrm{dl}$ (Table 3).

There is a significant inverse correlation between zinc level and PELD score (Pearson correlation $=-0.314, P$ $=0.007$ )

The distribution of magnesium levels was abnormal (Fig. 2). There was a significant difference between children with liver cirrhosis and the normal population in terms of the level of magnesium using the chi-square test $\left(\chi^{2}=32.67, P=0.0001\right)$ (Table 3$)$. Magnesium level according to etiology of cirrhosis is shown in Fig. 3.

There was a significant difference between the level of vitamin $\mathrm{D}$ among children with liver cirrhosis and normal level (chi-square $=4, P=0.0455$ ) (Table 2). There was no significant correlation between vitamin $D$ level and PELD score (Pearson correlation $=-0.205, P=$ 0.058). Vitamin D, zinc, and magnesium levels according to underlying disease are shown in Table 4. As seen 


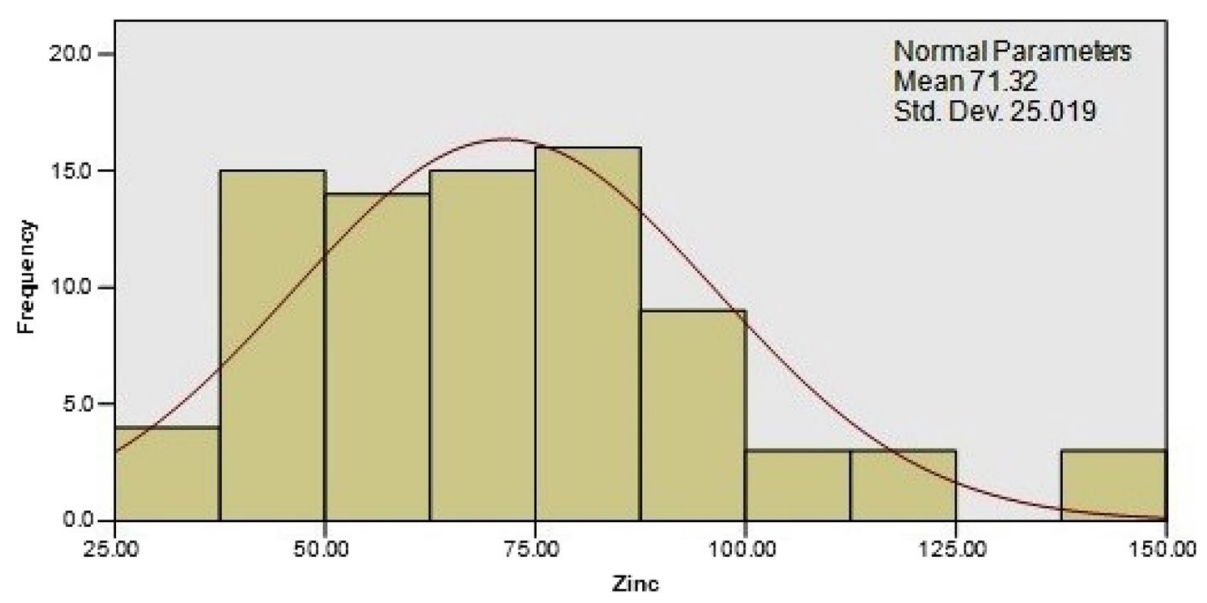

Fig. 1 Zinc level among children with liver cirrhosis

Table 3 Magnesium, zinc, and vitamin D level among children with liver cirrhosis

\begin{tabular}{llllllll}
\hline & Normal range & Median & Mean \pm SE & $\begin{array}{l}\text { Higher than } \\
\text { normal }\end{array}$ & $\begin{array}{l}\text { Lower than } \\
\text { normal }\end{array}$ & $\begin{array}{l}\text { Within normal } \\
\text { range }\end{array}$ & $\begin{array}{l}\text { Range (min, max) } \\
\text { Magnesium }\end{array}$ \\
\hline Zinc & $0.8-1 \mathrm{mmol} / \mathrm{L}$ & 2.1 & $2.07 \pm 0.275$ & $99 \%$ & - & $1 \%$ & $0.93-2.6$ \\
Vitamin D & $50-150 \mathrm{mcg} / \mathrm{dl}$ & 69.7 & $71.32 \pm 25.01$ & - & $23 \%$ & $77 \%$ & $25 .-147.1 \mathrm{mcg} / \mathrm{dl}$ \\
\hline
\end{tabular}

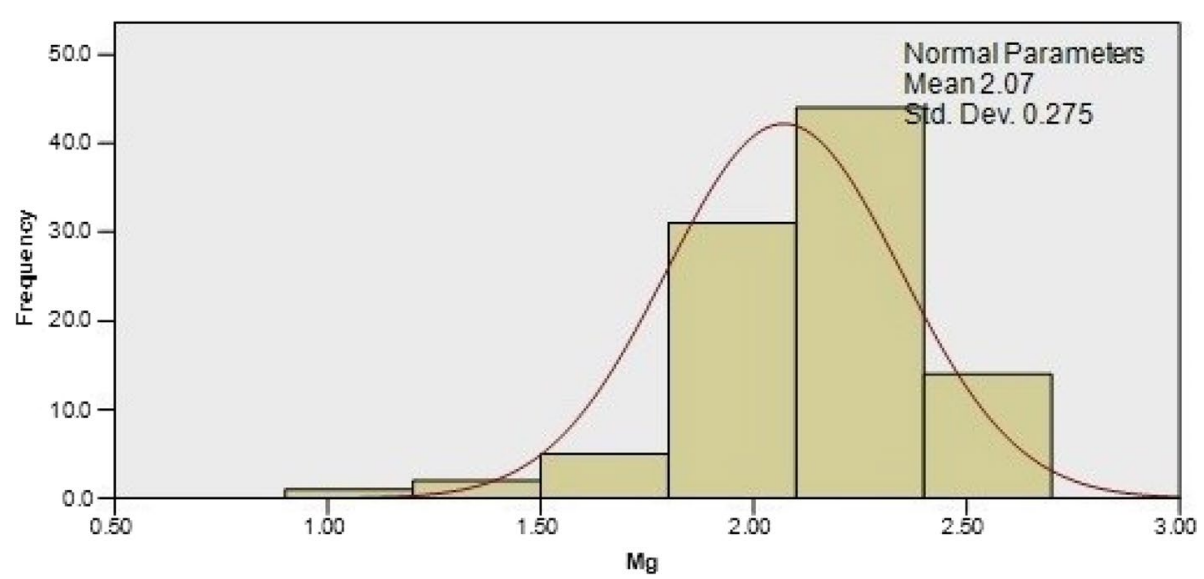

Fig. 2 Magnesium level among children with liver cirrhosis

in Table 4, the highest mean level of vitamin D was seen among PFIC patients. Vitamin D levels according to etiology of liver disease are shown in Fig. 4.

\section{Discussion}

The liver is the main organ for the metabolism of nutrients.
Our study showed that $53 \%$ of the children with liver cirrhosis had vitamin D deficiency. In the study by Jamil et al., vitamin $\mathrm{D}$ deficiency was found in $88 \%$ of patients with liver disease [10]. In the study by Paternostro et al., vitamin D deficiency was seen in $40 \%$ of the patients with liver cirrhosis [11]. In the study by Konstantakis et al., vitamin $\mathrm{D}$ deficiency had a great relationship with liver function [12]. In the study by Buonomo et al., vitamin D 


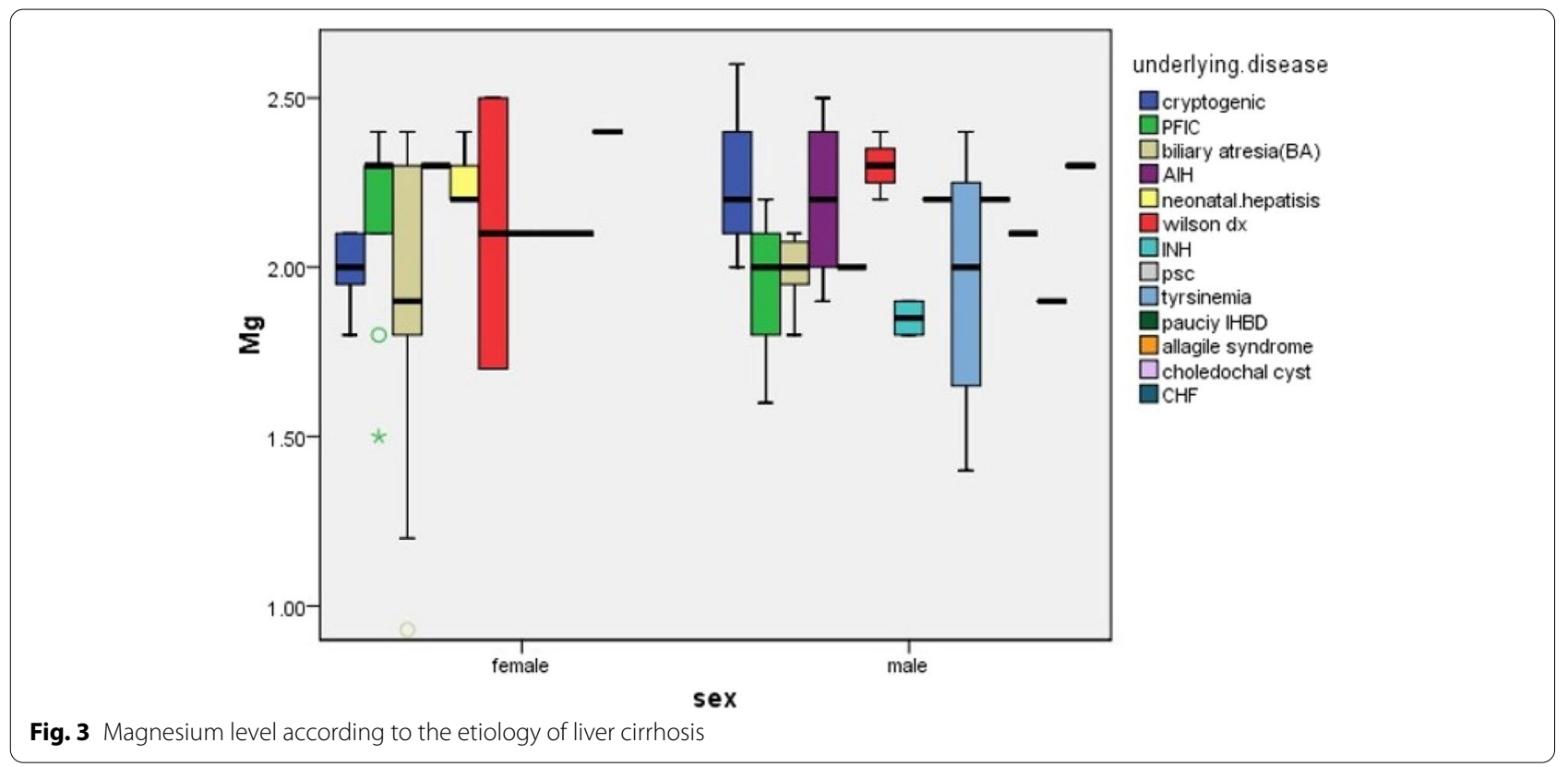

deficiency harmed the survival of the patients with liver cirrhosis [13]. We did not find a significant correlation between vitamin D level and PELD score. A significant correlation between vitamin 25-OH vitamin D3 level and poor outcome according to MELD and Child-Pugh score was found by Kim et al. [14].

Kumar et al. found that $80 \%$ of patients with liver cirrhosis had some degree of vitamin D deficiency [15]. In another study, $87 \%$ of patients with chronic liver disease showed insufficient or deficient vitamin D [16]. Vitamin $\mathrm{D}$ deficiency was shown in most studies. In the study by Jazayeri et al., the prevalence of vitamin D deficiency in Iranian boys and girls were $35 \%$ and $61 \%$, respectively [17]. The prevalence of vitamin D insufficiency in Iranian children and adolescents was 31\% [17]. As a result, the frequency of vitamin $\mathrm{D}$ deficiency was higher than healthy apparent Iranian children.

In the current study, magnesium level was higher than the normal level among 99\% of children with liver cirrhosis. But in the study by Kohen et al., magnesium deficiency was frequent among patients with liver cirrhosis [18]. In the study by Wang et al., magnesium deficiency was reported in patients with liver cirrhosis [19]. Significant changes in magnesium levels between patients with liver disease and the healthy population were not found in the study by Rahelic et al. [20]. In another study by Göksu and Ozsoylu, magnesium was decreased among children with liver cirrhosis [21]. Other studies had similar findings in terms of magnesium deficiency in liver cirrhosis [22]. Among Iranian healthy children, the prevalence of hypomagnesemia was 5.9\% [23]. Magnesium
Table 4 Magnesium, zinc, and vitamin D among children according to the underlying disease

\begin{tabular}{|c|c|c|c|c|}
\hline \multicolumn{2}{|c|}{ Underlying disease } & \multirow{2}{*}{$\begin{array}{l}\text { Vit. D (ng/dl) } \\
24\end{array}$} & \multirow{2}{*}{$\begin{array}{l}\mathrm{Mg}(\mathrm{mmol} / \mathrm{dl}) \\
24\end{array}$} & \multirow{2}{*}{$\begin{array}{l}\text { Zinc (mcg/dl) } \\
20\end{array}$} \\
\hline PFIC & $N$ & & & \\
\hline & Mean & 50.3267 & 2.0917 & 77.1900 \\
\hline \multirow{2}{*}{$\begin{array}{l}\text { Biliary atresia } \\
\text { (BA) }\end{array}$} & $N$ & 26 & 26 & 22 \\
\hline & Mean & 25.4619 & 1.9492 & 69.9045 \\
\hline \multirow[t]{2}{*}{ AlH } & $N$ & 6 & 5 & 5 \\
\hline & Mean & 35.7383 & 2.2200 & 56.2400 \\
\hline \multirow{2}{*}{$\begin{array}{l}\text { Neonatal } \\
\text { hepatitis }\end{array}$} & $N$ & 5 & 6 & 4 \\
\hline & Mean & 33.5080 & 2.2167 & 62.8750 \\
\hline \multirow[t]{2}{*}{ Wilson disease } & $N$ & 5 & 5 & 3 \\
\hline & Mean & 11.4880 & 2.2200 & 71.8667 \\
\hline \multirow[t]{2}{*}{$\mathrm{INH}$} & $N$ & 3 & 3 & 2 \\
\hline & Mean & 12.9900 & 1.9333 & 99.4500 \\
\hline \multirow[t]{2}{*}{ PSC } & $N$ & 2 & 2 & 2 \\
\hline & Mean & 34.1000 & 2.1500 & 47.0000 \\
\hline \multirow[t]{2}{*}{ Tyrosinemia } & $N$ & 5 & 5 & 5 \\
\hline & Mean & 39.23 & 1.98 & 81.06 \\
\hline \multirow[t]{2}{*}{ Paucity IHBD } & N & 2 & 2 & 2 \\
\hline & Mean & 18.87 & 2.30 & 87.00 \\
\hline \multirow{2}{*}{$\begin{array}{l}\text { Alagille syn- } \\
\text { drome }\end{array}$} & N & 1 & 1 & 1 \\
\hline & Mean & 6.27 & 2.10 & 89.00 \\
\hline \multirow{2}{*}{$\begin{array}{l}\text { Choledochal } \\
\text { cyst }\end{array}$} & N & 1 & 1 & 1 \\
\hline & Mean & 10.47 & 1.9000 & 76.00 \\
\hline \multirow[t]{2}{*}{$\mathrm{CHF}$} & $N$ & 1 & 1 & 1 \\
\hline & Mean & 23.7000 & 2.30 & 73.90 \\
\hline \multirow[t]{2}{*}{ Total } & N & 81 & 81 & 68 \\
\hline & Mean & 33.22 & 2.06 & 72.66 \\
\hline
\end{tabular}




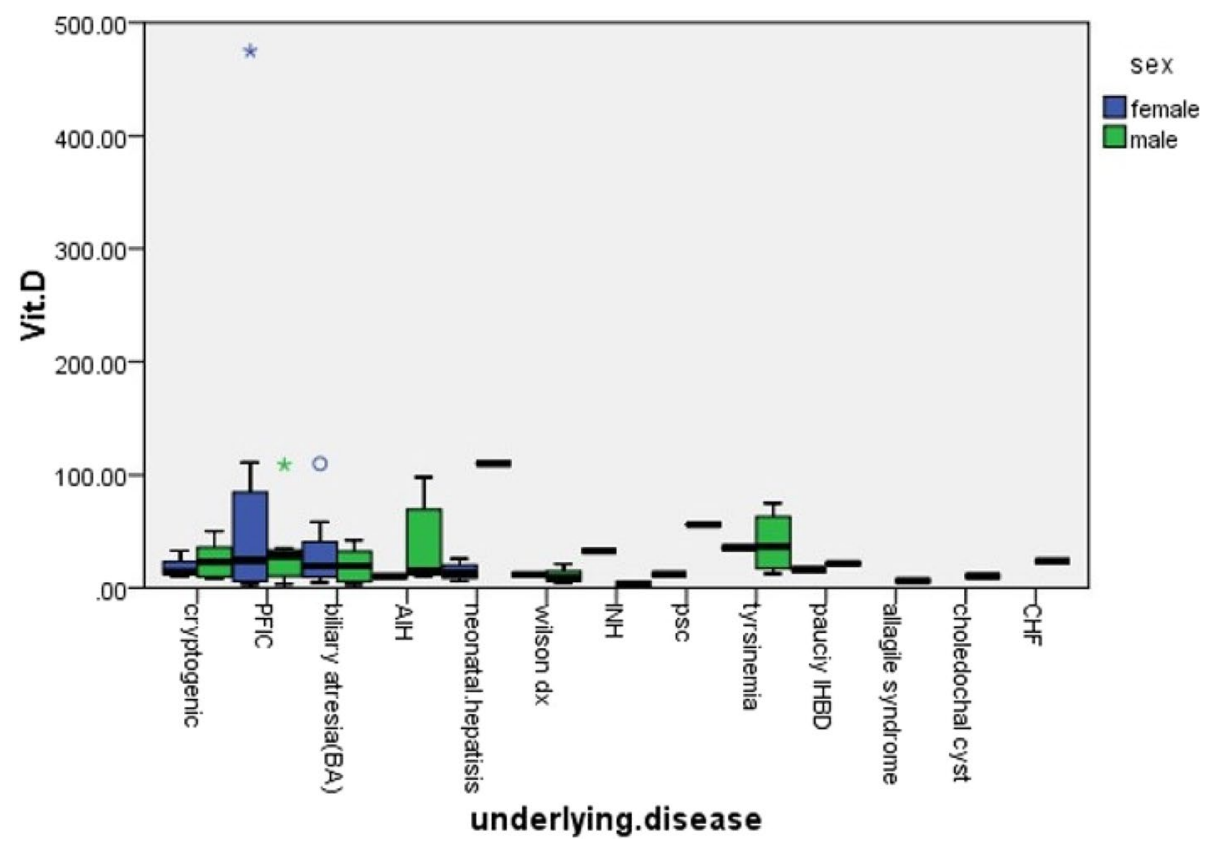

Fig. 4 Vitamin D level among different etiologies of cirrhosis

deficiency was expected in children with liver cirrhosis. But this difference has happened. Diet may have played an important role for example rice which was an important source of Iranian food [24]. Another study is recommended to find the cause of hypermagnesemia among children with liver cirrhosis.

Zinc deficiency was seen in $23 \%$ of children in our study. Zinc deficiency is a major health problem especially in developing countries [25]. Zinc deficiency was very frequent among developing countries rated between $46 \%$ in the Middle East and 79\% in South Asia [26, 27]. Even in Western European countries, the prevalence of zinc deficiency was high [28]. Zinc deficiency may lead to hepatic encephalopathy [29, 30]. Zinc deficiency was reported as a frequent finding among cirrhotic patients [31]. In the study by Katayama et al., zinc deficiency was common among patients with liver cirrhosis. In the study by Sengupta et al., zinc deficiency was highly prevalent among children with liver cirrhosis [32]. Sengupta and colleagues recommended screening for zinc deficiency [32]. In the study by Azemati et al. among 3500 Iranian healthy children aged 7-15 years, the prevalence of zinc deficiency was $5 \%$ [33]. In the study by Dehghani et al., the prevalence of zinc deficiency was $7.9 \%$ [27]. In the study by Dehghani et al. on 902 children without liver disease [27], zinc level was $122.3 \pm 55 \mathrm{mcg} / \mathrm{dl}$. The result of our study was lower than Dehghani et al.s study and show zinc level was lower in children with cirrhosis than in children without liver disease. Although due to the high frequency of zinc deficiency in the world [26], multiple factors play a role in zinc deficiency in children with liver cirrhosis. As a result, the prevalence of zinc deficiency among children with liver cirrhosis was higher than that among Iranian healthy apparent children [27]. According to the high prevalence of zinc deficiency in the world, cirrhosis may play as one factor in zinc deficiency.

\section{Conclusion}

Zinc and vitamin D deficiency was prevalent among children with liver cirrhosis. The serum magnesium level was higher in cirrhotic children compared to the standard level. Further studies are recommended to clarify changes in magnesium and zinc in children with liver cirrhosis with more samples.

\section{Limitation}

This study was a single-center study. In this study, we used standard values as the reference instead of healthy control. We used the standard level of zinc and magnesium for comparison. Due to the low sample size of some etiologies, some analysis was not possible. Dietic history was not included in the current research.

\section{Abbreviations}

AlH: Autoimmune hepatitis; CHF: Congenital hepatic fibrosis; INH: Idiopathic neonatal hepatitis; PELD Score: Pediatric Endstage Liver Disease Score; PFIC: Progressive familial intrahepatic cholestasis ; PSC: Primary sclerosing cholangitis. 


\begin{abstract}
Authors' contributions
SMD had the main idea and wrote the manuscript and also has a role in the revision of the manuscript. AA has arole in writing the manuscript and revision of the manuscript. PB has a role in data collection, writing a researchproposal, and data analysis. HJ performed the literature review and has a role in writing manuscript, revision ofmanuscript, and data analysis. All the authors read and approved the manuscript.
\end{abstract}

\section{Declarations}

\section{Competing interests}

The authors declare that they have no competing interests.

\begin{abstract}
Author details
${ }^{1}$ Gastroenterohepatology Research Center, Nemazee Teaching Hospital, Shiraz University of Medical Sciences, Shiraz, Iran. ${ }^{2}$ Dept. of Pediatric Endocrinology and Metabolism, Nemazee Teaching Hospital, Shiraz University of Medical Sciences, Shiraz, Iran. ${ }^{3}$ Dept. of Pediatrics, Nemazee Teaching Hospital, Shiraz University of Medical Sciences, Shiraz, Iran. ${ }^{4}$ Alimentary Tract Research Center, Ahvaz Jundishapur University of Medical Sciences, Clinical Sciences Research Institute, Ahvaz, Iran.
\end{abstract}

Received: 3 August 2021 Accepted: 13 February 2022

Published online: 24 February 2022

\section{References}

1. Alberino F, Gatta A, Amodio P, Merkel C, Di Pascoli L, Boffo G, Caregaro $L$ (2001) Nutrition and survival in patients with liver cirrhosis. Nutrition (Burbank, Los Angeles County, Calif) 17(6):445-450

2. Tajika M, Kato M, Mohri H, Miwa Y, Kato T, Ohnishi H, Moriwaki H (2002) Prognostic value of energy metabolism in patients with viral liver cirrhosis. Nutrition (Burbank, Los Angeles County, Calif) 18(3):229-234

3. Dehghani SM, Imanieh MH, Haghighat M, Malekpour A, Falizkar Z (2013) Etiology and complications of liver cirrhosis in children: report of a single center from southern Iran. Middle East J Digest Dis 5(1):41-46

4. Stamoulis I, Kouraklis G, Theocharis S (2007) Zinc and the liver: an active interaction. Dig Dis Sci 52(7):1595-1612

5. Capocaccia L, Merli M, Piat C, Servi R, Zullo A, Riggio O (1991) Zinc and other trace elements in liver cirrhosis. Italian J Gastroenterol 23(6):386-391

6. Shen YC, Chang YH, Fang CJ, Lin YS (2019) Zinc supplementation in patients with cirrhosis and hepatic encephalopathy: a systematic review and meta-analysis. Nutr J 18(1):34

7. Alsahhar JS, Rahimi RS (2019) Updates on the pathophysiology and therapeutic targets for hepatic encephalopathy. Curr Opin Gastroenterol 35(3):145-154

8. Oralewska B, Zawadzki J, Jankowska I, Popinska K, Socha J (1996) Disorders of magnesium homeostasis in the course of liver disease in children. Magnes Res 9(2):125-128

9. Ramadan HK, Makhlouf NA, Mahmoud AA, Abd Elrhman M, El-Masry MA (2019) Role of vitamin D deficiency as a risk factor for infections in cirrhotic patients. Clin Res Hepatol Gastroenterol 43(1):51-57

10. Jamil Z, Arif S, Khan A, Durrani AA, Yaqoob N (2018) Vitamin D deficiency and its relationship with child-Pugh class in patients with chronic liver disease. J Clin Transl Hepatol 6(2):135-140

11. Paternostro R, Wagner $D$, Reiberger $T$, Mandorfer $M$, Schwarzer $R$, Ferlitsch M, Trauner M, Peck-Radosavljevic M, Ferlitsch A (2017) Low 25-OH-vitamin $D$ levels reflect hepatic dysfunction and are associated with mortality in patients with liver cirrhosis. Wien Klin Wochenschr 129(1-2):8-15

12. Konstantakis C, Tselekouni P, Kalafateli M, Triantos C (2016) Vitamin D deficiency in patients with liver cirrhosis. Ann Gastroenterol 29(3):297-306

13. Buonomo AR, Scotto R, Zappulo E, Nerilli M, Pinchera B, Perruolo G, Formisano P, Nappa S, Gentile I (2019) Severe vitamin D deficiency increases mortality among patients with liver cirrhosis regardless of the presence of HCC. In vivo (Athens, Greece) 33(1):177-182

14. Kim TH, Yun SG, Choi J, Goh HG, Lee HA, Yim SY, Choi SJ, Lee YS, Yoon EL, Jung YK et al (2020) Differential impact of serum 25-hydroxyvitamin D3 levels on the prognosis of patients with liver cirrhosis according to MELD and child-Pugh scores. J Korean Med Sci 35(19):e129

15. Kumar R, Kumar P, Saxena KN, Mishra M, Mishra VK, Kumari A, Dwivedi M, Misra SP (2017) Vitamin D status in patients with cirrhosis of the liver and their relatives-a case control study from North India. Indian J Gastroenterol 36(1):50-55

16. Fernandez Fernandez $N$, Linares Torres $P$, Joao Matias $D$, Jorquera Plaza F, Olcoz Goni JL (2016) Vitamin D deficiency in chronic liver disease, clinicalepidemiological analysis and report after vitamin d supplementation. Gastroenterol Hepatol 39(5):305-310

17. Jazayeri M, Moradi Y, Rasti A, Nakhjavani M, Kamali M, Baradaran HR (2018) Prevalence of vitamin D deficiency in healthy Iranian children: a systematic review and meta-analysis. Med J Islam Repub Iran 32:83

18. Cohen-Hagai K, Feldman D, Turani-Feldman T, Hadary R, Lotan S, KitayCohen Y (2018) Magnesium deficiency and minimal hepatic encephalopathy among patients with compensated liver cirrhosis. Israel Med Assoc J: IMAJ 20(9):533-538

19. Wang FJ, Cao J, Ma LP, Jin ZX (2004) Study on cellular and serum concentration of calcium and magnesium in peripheral blood cells of cirrhosis. Zhonghua Gan Zang Bing Za Zhi 12(3):144-7.

20. Rahelic D, Kujundzic M, Romic Z, Brkic K, Petrovecki M (2006) Serum concentration of zinc, copper, manganese and magnesium in patients with liver cirrhosis. Collegium Antropologicum 30(3):523-528

21. Göksu N, Ozsoylu S (1986) Hepatic and serum levels of zinc, copper, and magnesium in childhood cirrhosis. J Pediatr Gastroenterol Nutr 5(3):459-462

22. Peng X, Xiang R, Li X, Tian H, Li C, Peng Z, Xiang M (2021) Magnesium deficiency in liver cirrhosis: a retrospective study. Scand J Gastroenterol 56(4):463-468

23. Ghasemi A, Syedmoradi L, Zahediasl S, Azizi F (2010) Pediatric reference values for serum magnesium levels in Iranian subjects. Scand J Clin Lab Invest 70(6):415-420

24. Shariatifar N, Rezaei M, Alizadeh Sani M, Alimohammadi M, Arabameri M (2020) Assessment of rice marketed in Iran with emphasis on toxic and essential elements; effect of different cooking methods. Biol Trace Elem Res 198(2):721-731

25. Maxfield L, Shukla S, Crane JS (2022) Zinc deficiency. In: StatPearls. StatPearls Publishing Copyright @ 2022, StatPearls Publishing LLC, Treasure Island

26. Maret W, Sandstead HH (2006) Zinc requirements and the risks and benefits of zinc supplementation. J Trace Elem Med Biol 20(1):3-18

27. Dehghani SM, Katibeh P, Haghighat M, Moravej H, Asadi S (2011) Prevalence of zinc deficiency in 3-18 years old children in shiraz-Iran. Iran Red Crescent Med J 13(1):4-8

28. Vreugdenhil M, Akkermans MD, van der Merwe LF, van Elburg RM, van Goudoever JB, Brus F (2021) Prevalence of zinc deficiency in healthy 1-3-year-old children from three Western European countries. Nutrients 13(11):3713. https://doi.org/10.3390/nu13113713.

29. Himoto T, Masaki T (2018) Associations between zinc deficiency and metabolic abnormalities in patients with chronic liver disease. Nutrients 10(1):88

30. McClain CJ, Antonow DR, Cohen DA, Shedlofsky SI (1986) Zinc metabolism in alcoholic liver disease. Alcohol Clin Exp Res 10(6):582-589

31. Katayama K, Kawaguchi T, Shiraishi K, Ito T, Suzuki K, Koreeda C, Ohtake T, Iwasa M, Tokumoto Y, Endo R et al (2018) The prevalence and implication of zinc deficiency in patients with chronic liver disease. J Clin Med Res 10(5):437-444

32. Sengupta S, Wroblewski K, Aronsohn A, Reau N, Reddy KG, Jensen D, Te $H$ (2015) Screening for zinc deficiency in patients with cirrhosis: when should we start? Dig Dis Sci 60(10):3130-3135

33. Azemati B, Khoramdad M, Qorbani M, Rastad H, Shafiee G, Heshmat R, Kelishadi R (2020) Percentile values of serum zinc concentration and prevalence of its deficiency in Iranian children and adolescents: the CASPIAN-V study. J Pediatr Endocrinol Metab 33(4):525-531

\section{Publisher's Note}

Springer Nature remains neutral with regard to jurisdictional claims in published maps and institutional affiliations. 